\title{
Augmented Reality for Student Learning Media: A Bibliometric Analysis and Visualization
}

\author{
Singgih Subiyantoro ${ }^{1 *}$, Baskoro Hadi², Eka Budhi Santosa ${ }^{3}$, Oka Irmade $^{4}$, Fatma Sukmawati ${ }^{5}$ \\ ${ }^{1}$ Universitas Veteran Bangun Nusantara \\ ${ }^{2}$ Yayasan Insan Teknolog dan Ahli Pendidikan Indonesia \\ 3,5 Universitas Sebelas Maret \\ ${ }^{4}$ Universitas Slamet Riyadi \\ E-mail: singgihsubiyantoro@univetbantara.ac.id \\ *Coresponding Author
}

Article History: Received: November 4, 2021; Accepted: November 28, 2021; Published: November 30, 2021

\begin{abstract}
Augmented Reality is a study that is now popular. Many researches theme have been published in various reputable journals. The purpose of this study is to provide an overview and visualization of Augmented Reality which is used as a medium of learning. This research is a qualitative research through descriptive analysis with literature review formed in bibliometric analysis which describes and visualizes ongoing phenomena as well as in the past regarding various topics related to Augmented Reality. Through the Scopus database source, there are 882 documents related to Augmented Reality were obtained from 2016 to 2020 and various data related to the number of documents by country, author, subject area, visualization of relationships between topics. Topics that are categorized as rare or have not been associated with AR will be an option for us to study more deeply so that it will give knowledge to the scientific of $A R$ as a medium for student learning.
\end{abstract}

Keywords: Augmented Reality, Bibliometric Analysis, Literature Review, Media.

\section{Copyright (c) 2021 The Author(s)}

This is an open access article under the CC BY-SA license.

\section{INTRODUCTION}

Education is the fundamental entity in the development of a nation. The achievement in managing education is determined by the quality of human resources. In an effort to improve the quality of human resources, it is necessary to improve the learning process in every level, one of them is high school level. Various forms of learning practices with various paradigms have been carried out, including the constructivism paradigm. Constructivism of learning explains that students create their own learning (Schunk, 2012). It encourages the teacher's role no longer as a learning center but as a facilitator, mediator and mentor. Likewise, students in the learning process do not only rely on the teacher but also must be active and have good learning independence so that the learning process takes place according to the expected goals. Similarly, learning independence is seen as one of the main competencies for 21st century students 
Subiyantoro, S. et al. | Augmented Reality for Student Learning Media: A Bibliometric Analysis and Visualization

(Wolters, 2010). In order to support independent learning, it needs media that can provide external motivation.

Technological developments are able to help limitations of learning. Digital technology is an open gateway to new alternative learning and options that support the acquisition of selfregulatory skills (Schneckenberg, Ehlers, \& Adelsberger, 2011). Augmented Reality (AR) is one of the uses of computer content technology that is raised in a real world environment (Wang, Callaghan, Bernhardt, \& White, 2017). AR technology refers to the inclusion of virtual elements in the view of the actual physical environment, to create mixed reality in real time (Miguel, Ruizrube, \& Manuel, 2018). AR can be applied to different devices such as smartphones, tablets, laptops, computers or head-mounted monitors (Miguel, Ruiz-rube, \& Manuel, 2018). AR can be applied to different devices such as smartphones, tablets, laptops, computers or head-mounted monitors (Pedaste, Mitt, \& Jürivete, 2020). AR provides the ability to overlay image, text, video, and audio components onto an existing image or space. AR technology has been able to bridge the gap and bring a more tangible learning approach. Student-centered activities can be enhanced by combining virtual and real-world experiences. In an effort to develop AR-based media, a needs analysis in learning is carried out.

\section{METHODS}

This research is a qualitative research with descriptive analysis techniques with literature studies which is equipped with bibliometric analysis where the study seeks to describe existing phenomena, that happen currently and in the past and it is added with various topics related to AR. This article highlighted the discussion of AR for student learning media with Scopus data sources from 2016 to 2020. The article metadata that has been obtained through the Publish or Perish software is then visualized and analyzed using the Vosviewer software.

\section{RESULTS AND DISCUSSION}

Results

Augmented Reality (AR) is one of the uses of computer content technology that is raised in a real world environment (Wang et al., 2017). AR technology refers to the inclusion of virtual elements in the view of the actual physical environment, to create mixed reality in real time (Miguel et al., 2018). Here is the concept of the position between AR, VR, and MR environments:

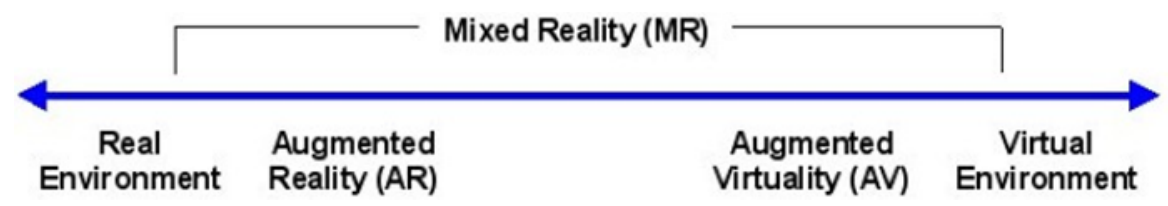

Figure1. Concept of Milgram's in (Ternier, Klemke, Kalz, \& Specht, 2012)

In an AR, where the virtual and physical worlds coexist, users learn while communicating with others in the same space (Martín-gutiérrez, Fabiani, Benesova, Dolores, \& Mora, 2015). AR is a technology that overlays virtual objects (added constituents) into the real world (Azuma, Behringer, Feiner, Julier, \& Macintyre, 2001). AR can be applied to different devices such as smartphones, tablets, laptops, computers or head-mounted monitors (Pedaste et al., 2020). AR provides opportunities based on this principle by combining printed text with virtual content (e.g., integrating video into a textbook) or by physically augmenting objects with virtual text (e.g., displaying informative text at the top of a screenshot of a historic building (Sommerauer \& Müller, 2015). 
Subiyantoro, S. et al. | Augmented Reality for Student Learning Media: A Bibliometric Analysis and Visualization

10 results of research on AR in learning are presented in the following table 1.

Table 1. AR Research Results in Learning

\begin{tabular}{|c|c|c|c|}
\hline No. & Authors & Title & Result \\
\hline 1 & $\begin{array}{l}\text { (Garzón, Pavón, } \\
\text { \& Baldiris, 2019) }\end{array}$ & $\begin{array}{l}\text { Systematic review and } \\
\text { meta-analysis of augmented } \\
\text { reality in educational settings }\end{array}$ & $\begin{array}{l}\text { The benefits from AR system in } \\
\text { education is "benefit of studying and } \\
\text { motivation" }\end{array}$ \\
\hline 2 & $\begin{array}{c}\text { (Parmaxi \& } \\
\text { Demetriou, 2020) }\end{array}$ & $\begin{array}{l}\text { Augmented reality in language } \\
\text { learning: A state-of-the-art } \\
\text { review of 2014-2019 }\end{array}$ & $\begin{array}{c}\text { The popularity of AR based on cellular } \\
\text { to support vocabulary }(23,9 \%), \\
\text { reading }(12,7 \%) \text {, speaking }(9,9 \%) \\
\text { writing }(8,5 \%) \text { or general language } \\
\text { ability }(9,9 \%) \text {. }\end{array}$ \\
\hline 3 & $\begin{array}{l}\text { (Fan, Antle, \& } \\
\text { Warren, 2020) }\end{array}$ & $\begin{array}{l}\text { Augmented Reality } \\
\text { for Early Language } \\
\text { Learning: A Systematic } \\
\text { Review of Augmented } \\
\text { Reality Application } \\
\text { Design, Instructional } \\
\text { Strategies, and } \\
\text { Evaluation Outcomes }\end{array}$ & $\begin{array}{c}\text { Revealing three AR learning activities: } \\
\text { spelling word game, activity } \\
\text { knowledge word, activity location } \\
\text { word. }\end{array}$ \\
\hline 4 & (Alzahrani, 2020) & $\begin{array}{l}\text { Augmented Reality: A Systematic } \\
\text { Review of Its } \\
\text { Benefits and Challenges in E- } \\
\text { learning Contexts }\end{array}$ & $\begin{array}{l}\text { AR increasing involvement, motivation, } \\
\text { caring / focus, interactivity, verbal } \\
\text { participation, consentration, } \\
\text { knowledge retension, and spasial } \\
\text { ability, also information aksesibility }\end{array}$ \\
\hline 5 & $\begin{array}{l}\text { (Khan, Johnston, } \\
\text { \& Ophoff, 2019) }\end{array}$ & $\begin{array}{l}\text { The Impact of an Augmented } \\
\text { Reality Application on } \\
\text { Learning Motivation of Students }\end{array}$ & $\begin{array}{l}\text { Caring, } \\
\text { Satisfying and increasing of motivation } \\
\text { belief factor, and this result find } \\
\text { significantly }\end{array}$ \\
\hline 6 & $\begin{array}{l}\text { (Arici, Yildirim, } \\
\text { Caliklar, \& } \\
\text { Yilmaz, 2019) }\end{array}$ & $\begin{array}{l}\text { Research trends in the use of } \\
\text { augmented reality in science } \\
\text { education: Content and } \\
\text { bibliometric mapping analysis }\end{array}$ & $\begin{array}{c}\text { "Motivation" and "Manner" have been } \\
\text { being the most researched variable in } \\
\text { article. }\end{array}$ \\
\hline 7 & (Chen, 2019) & $\begin{array}{c}\text { Effect of Mobile } \\
\text { Augmented Reality on } \\
\text { Learning Performance, } \\
\text { Motivation, and Math } \\
\text { Anxiety in a Math } \\
\text { Course }\end{array}$ & $\begin{array}{l}\text { AR group work better than non AR- } \\
\text { Group. }\end{array}$ \\
\hline 8 & (Ng et al., 2019) & $\begin{array}{l}\text { Effectiveness of virtual and } \\
\text { augmented reality-enhanced } \\
\text { exercise on } \\
\text { physical activity, psychological } \\
\text { outcomes, and physical } \\
\text { performance: A } \\
\text { systematic review and meta- } \\
\text { analysis of randomized } \\
\text { controlled trials }\end{array}$ & $\begin{array}{l}\text { VR training programe proven } \\
\text { increasing frequency of physical } \\
\text { activity and the power of physical } \\
\text { performance effectively }\end{array}$ \\
\hline 9 & $\begin{array}{l}\text { (Pedaste et al., } \\
\text { 2020) }\end{array}$ & $\begin{array}{c}\text { What Is the E } \\
\text { ect of Using Mobile Augmented } \\
\text { Reality in K12 Inquiry-Based } \\
\text { Learning? }\end{array}$ & $\begin{array}{l}\text { AR, in inquiry basis learning context, } \\
\text { for the most part is applied } \\
\text { successfully to achieve cognitif and, } \\
\text { It is seldom, motivating dan emotional } \\
\text { learning goals }\end{array}$ \\
\hline
\end{tabular}


Subiyantoro, S. et al. | Augmented Reality for Student Learning Media: A Bibliometric Analysis and Visualization

\begin{tabular}{ccc}
\hline $10 \quad$ (Kaplan et al., & The Effects of Virtual Reality, \\
2020) & $\begin{array}{c}\text { In some studies, reality that wider is as } \\
\text { effective as general training } \\
\text { Reality as Training Enhancement }\end{array}$ & $\begin{array}{c}\text { mechanism } \\
\text { Methods: } A\end{array}$ \\
Meta-Analysis & \\
\hline
\end{tabular}

Through the Scopus database source based on search keywords TITLE-ABS-KEY ( augmented AND reality) AND ( LIMIT-TO (PUBYEAR, 2020) OR LIMIT-TO ( PUBYEAR, 2019 ) OR LIMIT-TO ( PUBYEAR, 2018) OR LIMIT-TO (PUBYEAR, 2017) OR LIMIT-TO ( PUBYEAR , 2016 )) AND ( LIMIT-TO ( DOCTYPE, "cp" )) AND ( LIMIT-TO (SUBJAREA, "SOCI")) AND ( LIMIT-TO ( EXACTKEYWORD, "Augmented Reality" ) ) obtained 882 documents related to Augmented Reality from 2016 to 2020.

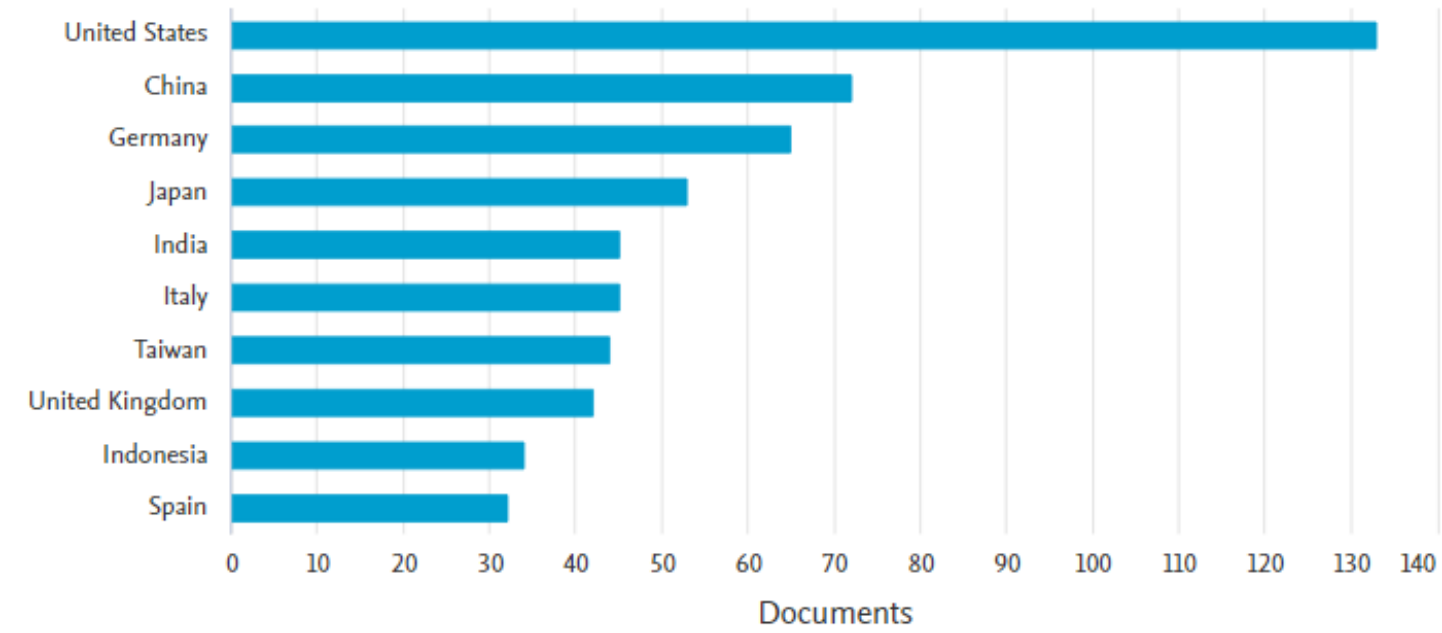

Figure 2. Documents by country or territory

Based on Figure 2, we can see that the top 10 countries that produced the most articles are: United States with 133 documents, China with 72 documents, Germany with 65 documents, Japan with 53 documents, India with 45 documents, Italy with 45 documents, Taiwan with 44 documents, United Kingdom with 42 documents, Indonesia with 34 documents, and Spain with 32 documents. 
Subiyantoro, S. et al. | Augmented Reality for Student Learning Media: A Bibliometric Analysis and Visualization

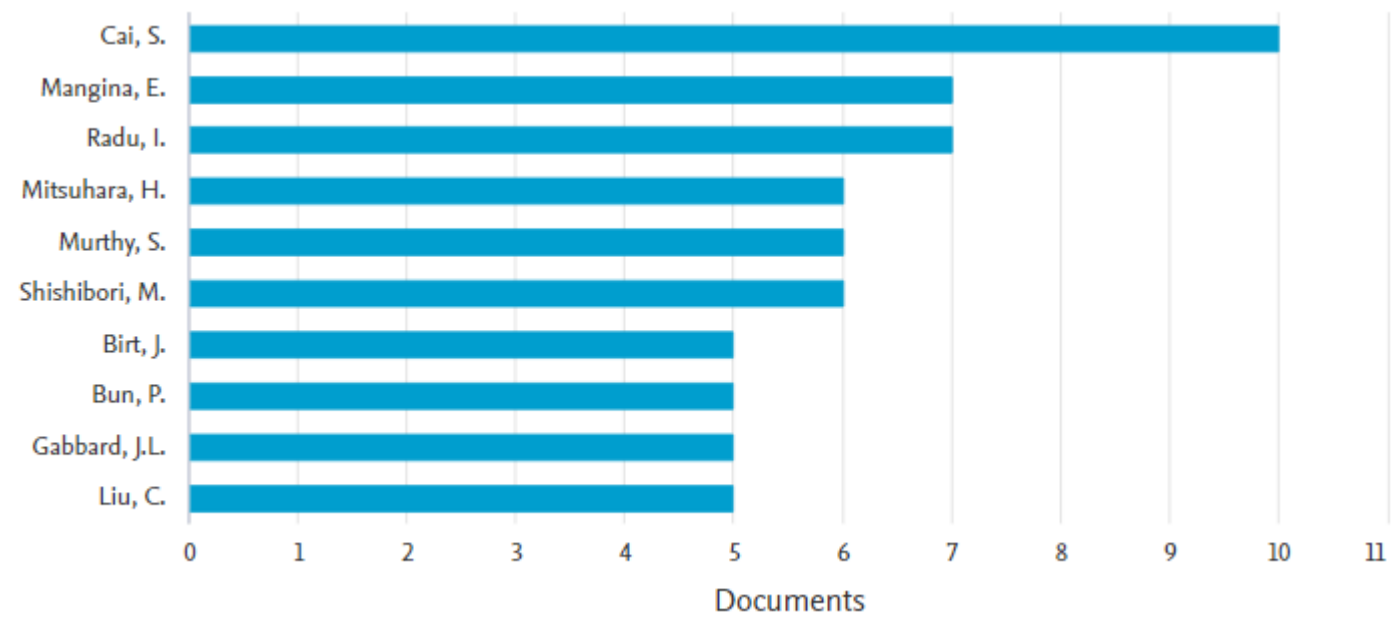

Figure 3. Documents by author

Based on Figure 3, we can see that the top 10 author positions are: Cai, S. with 10 documents, Mangina, E. with 7 documents, Radu, I. with 7 documents, Mitsuhara, H. with 6 documents, Murthy, S. with 6 documents, Shishibori, M. with 6 documents, Birt, J. with 5 documents, Bun, P. with 5 documents, Gabbard, JL with 5 documents, and Liu, C. with 5 documents.

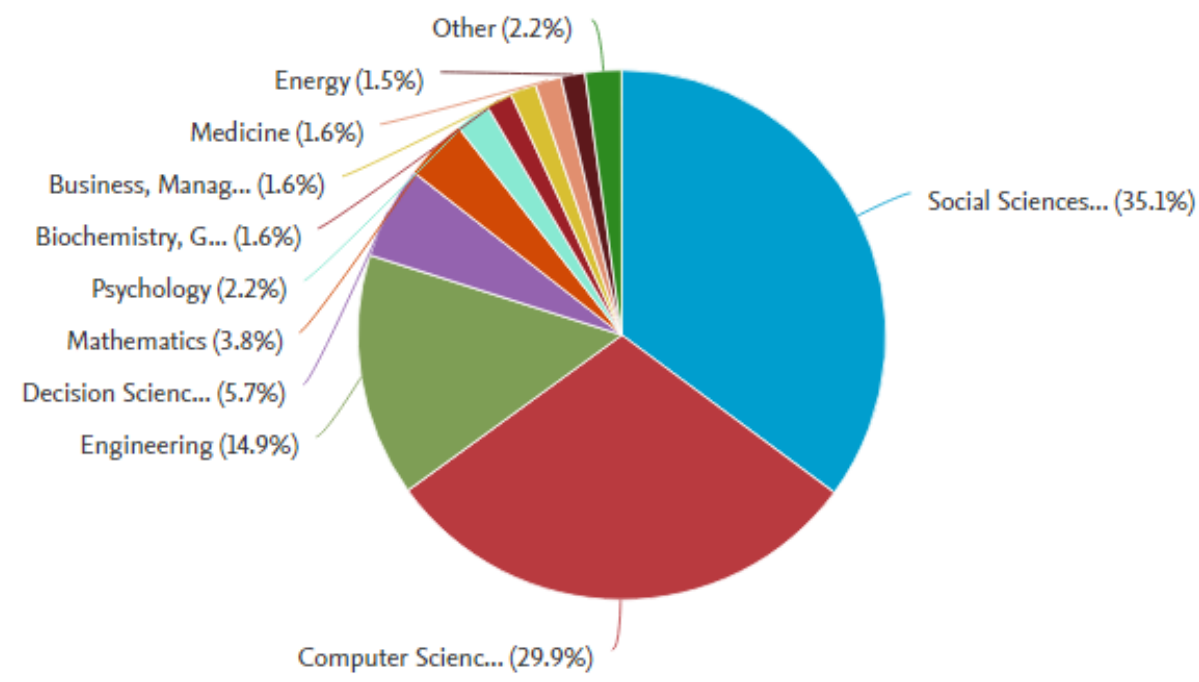

Figure 4. Documents by subject area

Based on Figure 4, the 5 largest categories of articles based on their fields are: Social Sciences with 35.1\%, Computer Science 29.9\%, Engineering 14.9\%, Decision Sciences with 5.7\%, and Mathematics with $3.8 \%$.

Then the data taken in RIS format is visualized with VOSviewer as shown below: 
Subiyantoro, S. et al. | Augmented Reality for Student Learning Media: A Bibliometric Analysis and Visualization

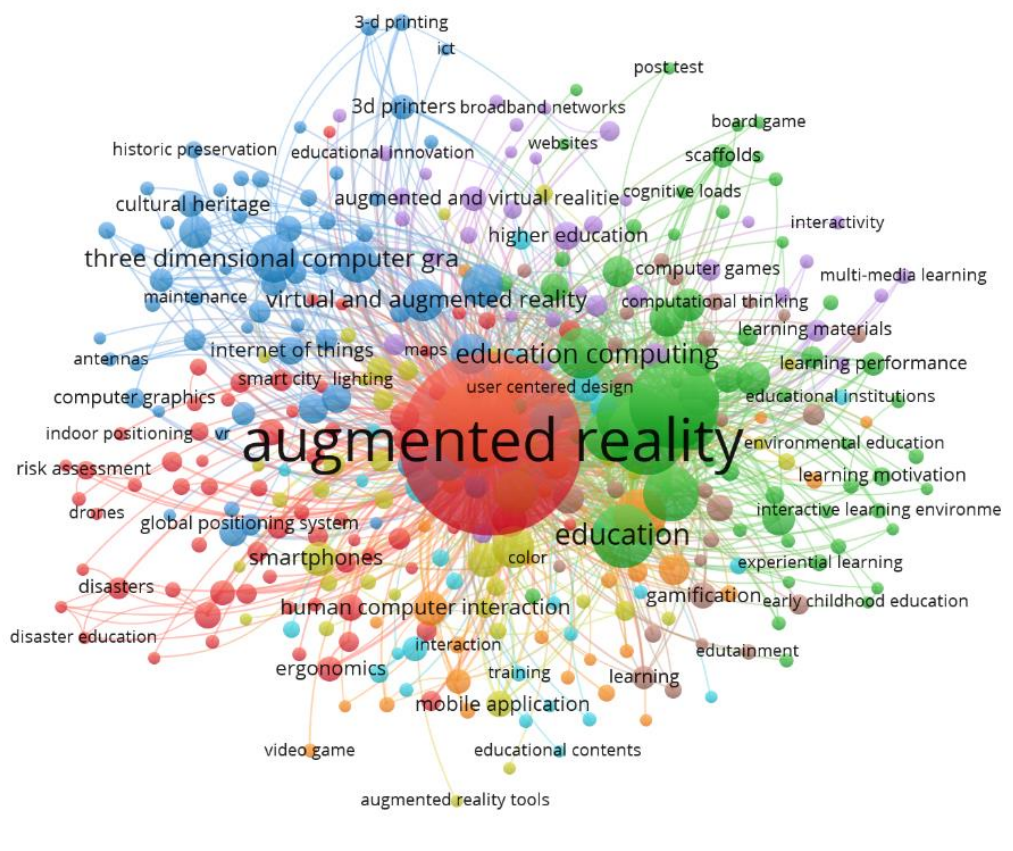

Figure 5. Overlay Visualization

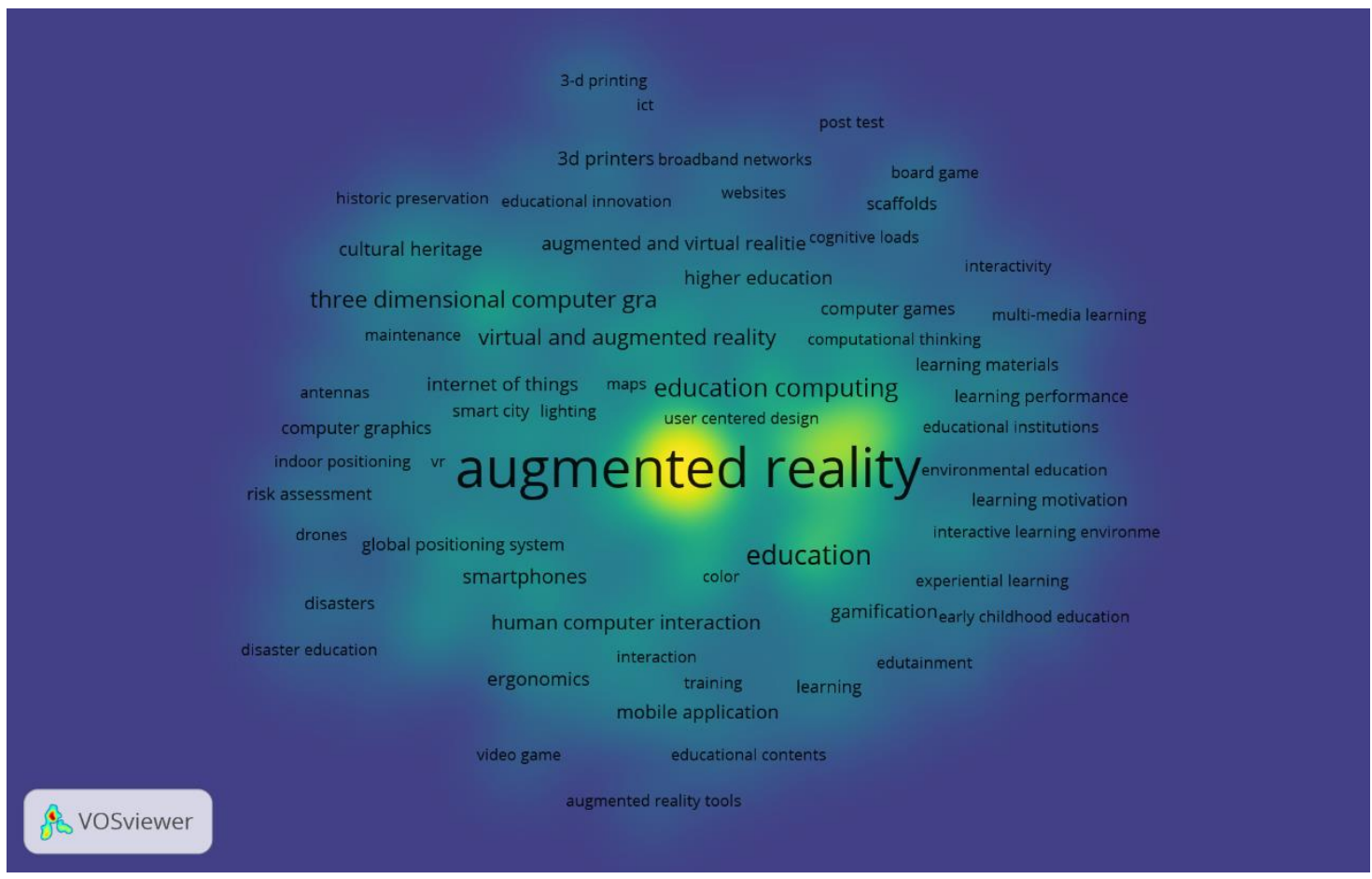

Figure 6. Density Visualization

Based on Figure 6, we can see the appearance of research topics related to Augmented Reality that have a relationship each other, some are close in distance, it means that the relationship is stronger than others. The larger size of circle or writing, the more topic is researched. Based on 
Subiyantoro, S. et al. | Augmented Reality for Student Learning Media: A Bibliometric Analysis and Visualization

Figure 7, it can be seen that the color display depends on the density of the items at the point. Yellow color means denser or often discussed than green and blue. So that we can map topics that have not been studied much related to AR.

\section{Discussion}

Various benefits in the application of AR technology in education have been investigated. AR technology can improve students' laboratory skills and help them build positive attitudes towards physics laboratories (Akçayır, Akçayır, Pektas, \& Ocak, 2016). The use of Augmented Reality on mobile applications can increase the learning motivation of health science undergraduate students. Attention, satisfaction, and motivational belief factors increased, and these results were significant (Khan et al., 2019). The application of AR in mathematics learning resulted in better learning performance, motivation and anxiety levels than the group without AR (Chen, 2019).

Based on the various benefits derived from implementing AR in learning, Augmented Reality technology allows students the freedom to actively experience digital content and integrate new information into their existing knowledge base individually. Thus, the AR learning experience is very much in line with the principles of constructivism (Wang et al., 2017). The various visualized topics surrounding the currently researched $A R$ that have been published in the journal Scopus have provided important information. For us, Topics that are categorized as rare or have not been associated with AR will be an option for us to study more deeply so that it will add to the scientific repertoire of AR.

\section{CONCLUSION}

Augmented reality is one of the alternative media that is currently being studied in the scope of learning from various disciplines. Various benefits of AR media have been researched and published in various journals, especially journals that have been indexed by Scopus. Writers in Asia, namely Indonesia, also contributed to the top 10 in the number of publications based on their country. The trend of research on AR will continue to grow with new learning approaches that will also make more use of the virtual environment.

However, the utilization of the literature obtained in research and the use of applications in analyzing this data can still be said to be limited. There are still many data sources other than Scopus that can be used. For future research, data sources from the web of science or other sources can be added. Likewise, to analyze bibliometric data, applications other than VOSviewer can be added to complete the visualization.

\section{CONFLICT OF INTEREST}

The authors declare that there is no conflict of interest regarding the publication of this article. Authors confirmed that the paper was free of plagiarism.

\section{ACKNOWLEDGEMENTS (OPTIONAL)}

A big thank you to all ITAPI management and Accounting MGMP at SMK Central Java who have contributed a lot to help in the research process. Thanks also to the Directorate General of Teachers and Education Personnel of the Ministry of Education and Culture of the Republic of Indonesia for funding so that this research can be carried out. 
Subiyantoro, S. et al. | Augmented Reality for Student Learning Media: A Bibliometric Analysis and Visualization

\section{REFERENCES}

Akçayır, M., Akçayır, G., Pektas, H. M., \& Ocak, M. A. (2016). Augmented reality in science laboratories : The effects of augmented reality on university students ' laboratory skills and attitudes toward science laboratories. Computers in Human Behavior, 57, 334-342. https://doi.org/10.1016/j.chb.2015.12.054

Alzahrani, N. M. (2020). Augmented Reality : A Systematic Review of Its Benefits and Challenges in E-learning Contexts. Applied Sciences, (10). https://doi.org/10.3390/app10165660

Arici, F., Yildirim, P., Caliklar, Ş., \& Yilmaz, R. M. (2019). Research trends in the use of augmented reality in science education : Content and bibliometric mapping analysis. Computers \& Education, 142(August), 103647. https://doi.org/10.1016/j.compedu.2019.103647

Azuma, R., Behringer, R., Feiner, S., Julier, S., \& Macintyre, B. (2001). Recent Advances in Augmented Reality. IEEE Computer Graphics and Applications, (December). https://doi.org/10.1109/38.963459

Chen, Y. (2019). Effect of Mobile Augmented Reality on Learning Performance, Motivation , and Math Anxiety in a Math Course. Journal of Educational Computing. https://doi.org/10.1177/0735633119854036

Fan, M., Antle, A. N., \& Warren, J. L. (2020). Augmented Reality for Early Language Learning : A Systematic Review of Augmented Reality Application Design , Instructional Strategies , and Evaluation Outcomes. Journal of Educational Computing Research, (1), 1-42. https://doi.org/10.1177/0735633120927489

Garzón, J., Pavón, J., \& Baldiris, S. (2019). Systematic review and meta - analysis of augmented reality in educational settings. Virtual Reality, (0123456789). https://doi.org/10.1007/s10055-019-00379-9

Kaplan, A. D., Cruit, J., Florida, C., Technologies, S. A., Canyon, G., Beers, S. M., ... Hancock, P. A. (2020). The Effects of Virtual Reality, Augmented Reality , and Mixed Reality as Training Enhancement Methods : A Meta- Analysis. Human Factors. https://doi.org/10.1177/0018720820904229

Khan, T., Johnston, K., \& Ophoff, J. (2019). The Impact of an Augmented Reality Application on Learning Motivation of Students. Journal Advances in Human-Computer Interaction. https://doi.org/10.1155/2019/7208494

Martín-gutiérrez, J., Fabiani, P., Benesova, W., Dolores, M., \& Mora, C. E. (2015). Augmented reality to promote collaborative and autonomous learning in higher education.

Computers in Human Behavior, 51, 752-761. https://doi.org/10.1016/j.chb.2014.11.093

Miguel, J., Ruiz-rube, I., \& Manuel, J. (2018). Augmented reality mobile app development for all. Computers and Electrical Engineering, 65, 250-260. https://doi.org/10.1016/j.compeleceng.2017.08.025

$\mathrm{Ng}$, Y., Ma, F., Ho, F. K., Ip, P., Fu, K., Kong, H., \& Kong, H. (2019). Effectiveness of virtual and augmented reality-enhanced exercise on physical activity, psychological outcomes, and physical performance : A systematic review and meta-analysis of randomized controlled trials. Computers in Human Behavior, 99(May), 278-291. https://doi.org/10.1016/j.chb.2019.05.026

Parmaxi, A., \& Demetriou, A. A. (2020). Augmented reality in language learning : A state-ofthe-art review of 2014 - 2019. Journal of Computer Assisted Learning, (July), 1-15. https://doi.org/10.1111/jcal.12486

Pedaste, M., Mitt, G., \& Jürivete, T. (2020). What Is the Effect of Using Mobile Augmented. Education Science. https://doi.org/10.3390/educsci10040094 
Subiyantoro, S. et al. | Augmented Reality for Student Learning Media: A Bibliometric Analysis and Visualization

Schneckenberg, D., Ehlers, U., \& Adelsberger, H. (2011). learning - Potentials and implications for higher education. British Journal of Educational Technology, 42(5), 747-762. https://doi.org/10.1111/j.1467-8535.2010.01092.x

Schunk, D. H. (2012). Learning Theories An Educational Perspective. (P. Smith, Ed.) (6th ed.). Boston: PEARSON.

Sommerauer, P., \& Müller, O. (2015). Augmented reality in informal learning environments : A fi eld experiment in a mathematics exhibition. Computers \& Education, 79(2014), 59-68. https://doi.org/10.1016/j.compedu.2014.07.013

Ternier, S., Klemke, R., Kalz, M., \& Specht, M. (2012). ARLearn : Augmented Reality Meets Augmented Virtuality. Journal of Universal Computer Science, 18(15), 2143-2164.

Wang, M., Callaghan, V., Bernhardt, J., \& White, K. (2017). Augmented reality in education and training : pedagogical approaches and illustrative case studies. Journal of Ambient Intelligence and Humanized Computing, 0(0), 0. https://doi.org/10.1007/s12652-0170547-8

Wolters, C. (2010). Self-regulated Learning and the 21 St Century Competencies. http://www.hewlett.org/uploads/Self_Regulated_Learning_21st_Century_Competencie s.pdf 